\title{
The effect of antihypertensive drugs on chronic kidney disease: a comprehensive review
}

\author{
Anastasia G Ptinopoulou, Maria I Pikilidou and Anastasios N Lasaridis \\ Data from randomized clinical trials and epidemiological evidence identify systemic hypertension as the second most common \\ modifiable risk factor for chronic kidney disease (CKD) progression after diabetes mellitus. CKD may progress silently over \\ the years and early diagnosis and control of hypertension is of major importance in delaying renal function decline. Recent \\ guidelines for the treatment of hypertension suggest the use of a variety of antihypertensive drugs in order to achieve the \\ desired blood pressure levels. Renin-angiotensin system inhibitors have been undoubtedly studied the most and are suggested \\ by guidelines and experts as first choice in patients with hypertension and renal injury, particularly in those with diabetes, as \\ they have repeatedly shown to significantly reduce proteinuria. Other classes of antihypertensive drugs have been studied to \\ a lesser extent and they have their own unique properties and effects. However, it is now common knowledge that adequate \\ blood pressure control is the most important factor for the preservation of renal function, so every drug that effectively lowers \\ hypertension is believed to be renoprotective. The present article will review the latest data on the role and properties of each \\ class of antihypertensive drugs on CKD.
}

Hypertension Research (2013) 36, 91-101; doi:10.1038/hr.2012.157; published online 11 October 2012

Keywords: antihypertensive drugs; blood pressure control; chronic kidney disease; renal protection

\section{INTRODUCTION}

Chronic kidney disease (CKD) is a growing health problem of epidemic proportions worldwide. The National Kidney Foundation Kidney Disease Outcomes Quality Initiative (NKF KDOQI) guidelines define CKD as structural or functional abnormalities of the kidney for $\geqslant 3$ months, manifested by either pathological abnormalities or markers of kidney damage, including persistent proteinuria, with or without decreased glomerular filtration rate (GFR), or as decrease in GFR $<60 \mathrm{ml} \mathrm{min}^{-1}$ per $1.73 \mathrm{~m}^{2}$ for $\geqslant 3$ months, with or without kidney damage. ${ }^{1}$ CKD may progress silently over many years.

Data from randomized clinical trials and epidemiological evidence identify systemic hypertension as the second most common modifiable risk factor for CKD progression after diabetes mellitus. ${ }^{2-4}$ High levels of hypertension have been strongly associated with faster decline of renal function in the Modification of Diet in Renal Disease (MDRD) study, especially in persons with higher baseline proteinuria. ${ }^{5}$ In addition, a strong relation between the estimated risk of end-stage renal disease (ESRD) and the elevations of BP was identified in the Multiple Risk Factor Intervention Trial (MRFIT), which followed up 332544 men, 35-57 years of age, for 16 years. $^{6}$ The United States Renal Data System (USRDS) data indicate that hypertension is the main cause for more than a quarter of the ESRD patients treated in the United States and although a variety of antihypertensive drugs are available, the rate of ESRD due to hypertension has grown by $8.7 \%$ since $2000 .^{2}$
Patients with CKD are at increased risk for cardiovascular disease. It is well established that microalbuminuria and reduced GFR, in both diabetic and nondiabetic hypertensive patients, are major cardiovascular risk factors and many older patients develop or die from cardiovascular disease rather than progress to ESRD. Antihypertensive and Lipid-Lowering Treatment to Prevent Heart Attack Trial (ALLHAT) findings supported that chlorthalidone was superior to other agents in preventing one or more major forms of cardiovascular disease, although no significant difference was found in all-cause mortality. ${ }^{7}$ In addition, in participants with an estimated GFR $<60 \mathrm{ml} \mathrm{min}^{-1}$, there was no significant difference in cardiovascular mortality between different treatment groups. ${ }^{8}$ Moreover, Staessen et $a .^{9}$ in their meta-analysis showed that the level of blood-pressure control was a more significant predictor of cardiovascular disease outcomes than the use of newer antihypertensive agents.

According to the 2007 European Society of Hypertension and European Society of Cardiology (ESH-ESC) guidelines ${ }^{10}$ and the Seventh Report of the Joint National Committee on Prevention, Detection, Evaluation and Treatment of High Blood Pressure (JNC7), ${ }^{11} \mathrm{BP}$ goal is set to $<130 / 80 \mathrm{~mm} \mathrm{Hg}$ in patients with renal dysfunction and $<125 / 75 \mathrm{~mm} \mathrm{Hg}$ if proteinuria is $>1 \mathrm{~g}$ per day. ${ }^{12}$ However, this is not consistently supported by trial evidence, and on this basis, ESH changed BP goal to $130-139 / 80-85 \mathrm{~mm} \mathrm{Hg} .{ }^{13}$ Still, the optimal BP goals remain controversial. ${ }^{14}$ It is believed that any drug that lowers hypertension is renoprotective. However, some

Division of Nephrology and Hypertension, First Department of Internal Medicine, AHEPA Hospital, Aristotle University of Thessaloniki, Thessaloniki, Greece

Correspondence: Dr AG Ptinopoulou, Division of Nephrology and Hypertension, First Department of Internal Medicine, AHEPA Hospital, Aristotle University of Thessaloniki, St Kiriakidi 1, Thessaloniki 54636, Greece.

E-mail: anastasiap@gmx.com

Received 29 May 2012; revised 10 August 2012; accepted 14 August 2012; published online 11 October 2012 
antihypertensive drugs have additional renoprotective effects that are independent to the BP lowering effect, like proteinuria reduction. ${ }^{15,16}$

Proteinuria, including both microalbuminuria and clinical proteinuria, has been recognized as a key predictor of kidney disease progression in the Prevention of Renal and Vascular End-stage Disease (PREVEND) study ${ }^{17,18}$ and clearly has a pathogenic role in loss of renal function, through proinflammatory and profibrogenetic injury in tubular cells, which can facilitate the development of interstitial fibrosis and tubular atrophy. ${ }^{19}$ Clinical evidence to date suggest that appropriate therapy can reduce the rate of microalbuminuria progression to macroalbuminuria and $\mathrm{CKD},{ }^{5,20}$ A large number of clinical studies have investigated the effect of antihypertensive treatment on renal function. The present article will review the latest data on the effect of each category of antihypertensive drugs on CKD.

\section{METHODS}

Clinical studies of relevance to the effect of antihypertensive drugs on CKD were identified by searching the MEDLINE and the Cochrane databases. In addition, relevant ongoing clinical trials were searched in the ClinicalTrials.gov registry. The primary search terms were antihypertensive drugs and renal disease, renal function, renoprotective, CKD or renal protection. Secondary search terms were angiotensinconverting enzyme inhibitors (ACEIs), angiotensin receptor blockers, renin inhibitors, aldosterone antagonists, calcium channel blockers (CCBs), diuretics, $\alpha$-blockers, $\beta$-blockers or centrally acting adrenergic drugs and $\mathrm{CKD}$ or renal function. Additional relevant publications were identified by searching the reference lists of obtained articles.

\section{RENIN-ANGIOTENSIN SYSTEM INHIBITORS}

The pathophysiology of the RAS underpins the therapeutic renal benefit of ACEIsand angiotensin II type 1 receptor blockers (ARBs). Angiotensin II acts on the kidneys and produces vasoconstriction of efferent arteriole in the glomerulus, which increases capillary pressure and filtration fraction. ${ }^{21}$ Moreover, angiotensin II enhances ultrafiltration of proteins and is associated with podocyte injury, resulting in proteinuria. ${ }^{19}$ Chronic activation of the RAS perpetuates a cascade of proinflammatory, prothrombotic and atherogenic effects associated with end-organ damage. ${ }^{22}$

\section{Diabetic nephropathy}

One of the first studies that examined the effect of ACEIs on diabetic nephropathy was published in 1993 by the Collaborative Study Group and reported that in 409 patients with type 1 diabetes mellitus and overt nephropathy captopril $25 \mathrm{mg}$ TID had a renoprotective effect compared with placebo that was independent of the BP reduction. ${ }^{23}$ The results of this study were later enhanced by larger studies, like the Microalbuminuria, Cardiovascular and Renal outcomes in the Heart Outcomes Prevention Evaluation study (MICRO-HOPE) that is a subset of the HOPE study, published in 2000, where the ACEI ramipril was shown to lower the risk of overt nephropathy by $24 \%$ $(P=0.027)$ in 3577 patients with diabetes mellitus, who had at least one other cardiovascular risk factor and no clinical proteinuria. ${ }^{24}$

Likewise, MicroAlbuminuria Reduction with VALsartan (MARVAL) and Irbesartan in Patients with Type 2 Diabetes and Microalbuminuria (IRMA 2) studies elucidated the beneficial effect of ARBs in patients with type 2 diabetes and microalbuminuria. The former showed that valsartan decreased albuminuria more than amlodipine (44 vs. $8 \%, P<0.001$ ) during 6 months $^{25}$ and the latter that only $5.2 \%$ of the group receiving $300 \mathrm{mg}$ of irbesartan and $9.7 \%$ of those receiving $150 \mathrm{mg}$ progressed to diabetic nephropathy during 2 years vs. $14.9 \%$ of the placebo group. ${ }^{26}$ IRMA 2 was followed by Irbesartan Diabetic Nephropathy Trial (IDNT), which involved subjects with overt nephropathy and showed a greater reduction of proteinuria in Irbesartan group than in amlodipine group (33 vs. $6 \%) .^{27,28}$ In a similar population, Reduction of Endpoints in Noninsulin-dependent diabetes mellitus with the Angiotensin II Antagonist Losartan (RENAAL) study ${ }^{15}$ reproduced IDNT findings. The important role of ARBs in diabetic nephropathy was also underlined in Siebenhofer et al. meta-analysis. ${ }^{29}$ In addition, the more recent Randomised Olmesartan and Diabetes Microalbuminuria Prevention (ROADMAP) study showed that in a large sample of type 2 diabetics $(n=4447)$, with at least one additional cardiovascular risk factor and normoalbuminuria, olmesartan delayed the onset of microalbuminuria by $23 \%$ compared with placebo group $(P=0.01)$, at a median follow-up of 3.2 years, independently of baseline $\mathrm{BP}$ and the degree of $\mathrm{BP}$ reduction (Table 1)..$^{30,31}$

Interpreting the results of important studies, NKF KDOQI guidelines on hypertension and antihypertensive agents in $\mathrm{CKD}^{12}$ suggest the use of ACEIs as first choice drugs for patients with type 1 diabetes mellitus and ARBs for subjects with type 2 diabetes mellitus. Diabetics Exposed to Telmisartan and Enalapril Trial (DETAIL) ${ }^{32}$ is the only long-lasting study that compares the two drug categories. According to the study results, ACEIs and ARBs did not differ significantly in reducing GFR decline in subjects with type 2 diabetes mellitus and nephropathy. ${ }^{33,34}$ However, some limitations of the study design, like the small size of the study, the small number of patients with macroalbuminuria and the large number of subjects with normal GFR, may lead to precarious conclusions.

\section{Nondiabetic (hypertensive) nephropathy}

Randomized clinical trials have firmly established the benefit of RAS inhibition in hypertensive nephropathy. The effect of antihypertensive treatment on progression of renal insufficiency in nondiabetic patients (ESPIRAL) trial ${ }^{35}$ compared the effect of fosinopril and a long-acting gastrointestinal therapeutic system (GITS) formulation of nifedipine on CKD progression in 241 hypertensive nondiabetic subjects. After 3 years of follow-up, $21 \%$ of patients treated with fosinopril and $36 \%$ of those receiving nifedipine GITS presented a primary end point (double serum creatinine values and/or need to enter a dialysis program). In addition, proteinuria decreased at the end of the study by a mean of $57 \%$ in the fosinopril group and increased by $7 \%$ in the group receiving dihydropiridine. The larger African American Study of Kidney Disease and Hypertension (AASK) trial $^{36}$ followed up on 1094 African Americans for 3 to 6.4 years and showed risk reductions in the clinical composite outcome of 22 $(P=0.04)$ and $38 \%(P=0.004)$ in ramipril group compared with metoprolol and amlodipine groups, respectively. Both studies proved that ACE inhibition had a renoprotective effect that is independent to the reduction of BP. This notion is enhanced by Ramipril Efficacy in Nephropathy (REIN) $)^{37}$ and REIN-2 $2^{38}$ studies in nondiabetic proteinuric subjects (Table 2).

In addition, a post-hoc analysis of the REIN trial showed that disease progression and response to ACE inhibition did not depend on the severity of renal insufficiency, although prevention of ESRD was found to be strongly dependent on treatment duration $(P<0.0001)$ and was maximized when ACEIs were started in earlier stages. ${ }^{39}$ ACEIs were also shown to be effective in advanced nondiabetic nephropathy by Hou et al., ${ }^{40}$ who followed up on 317 patients for a mean of 3.4 years and found that benazepril was beneficial in patients with stage $4 \mathrm{CKD}$. Nonetheless, patients with advanced CKD are particularly sensitive to the effects of ACEIs on the 


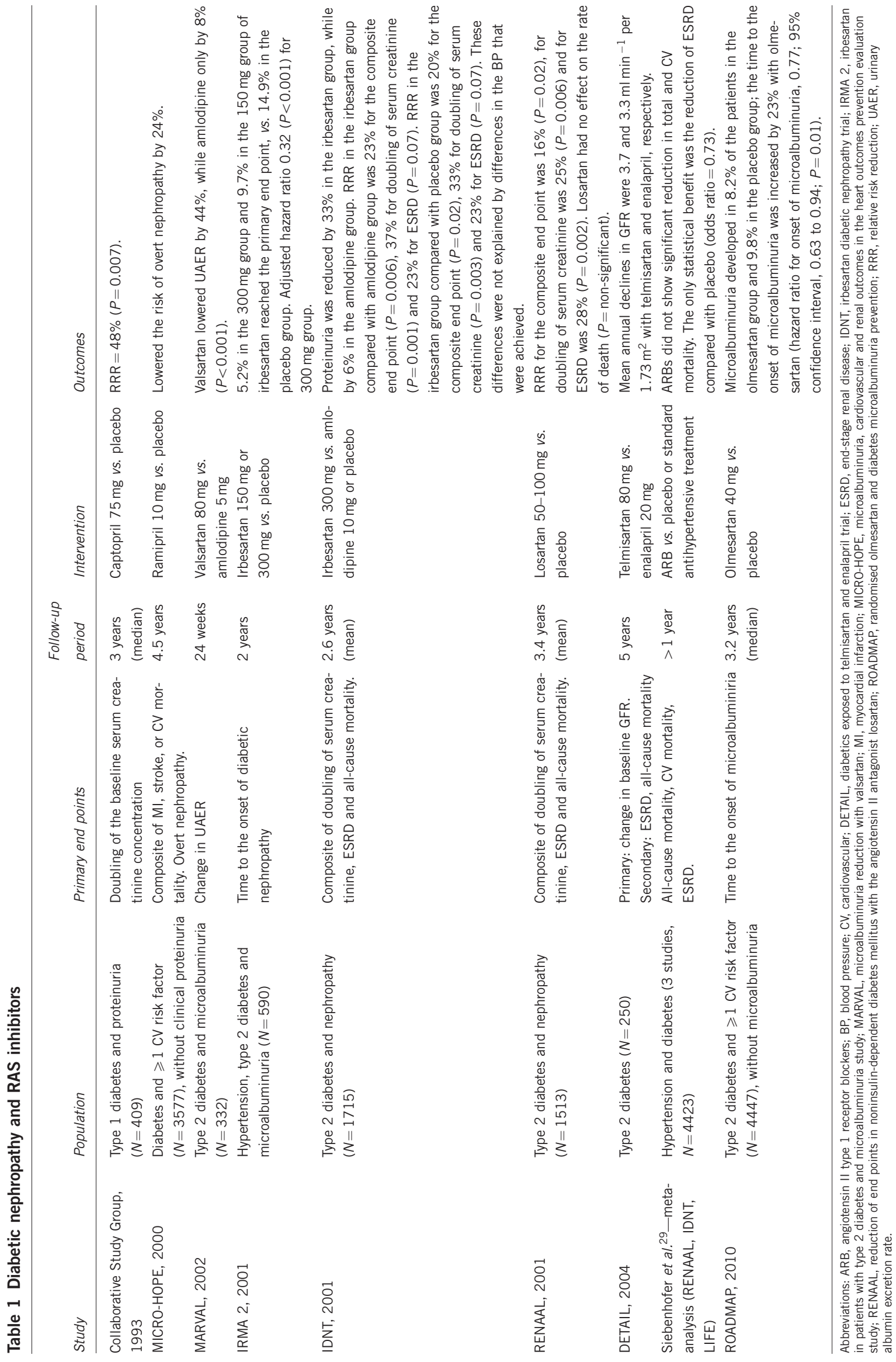




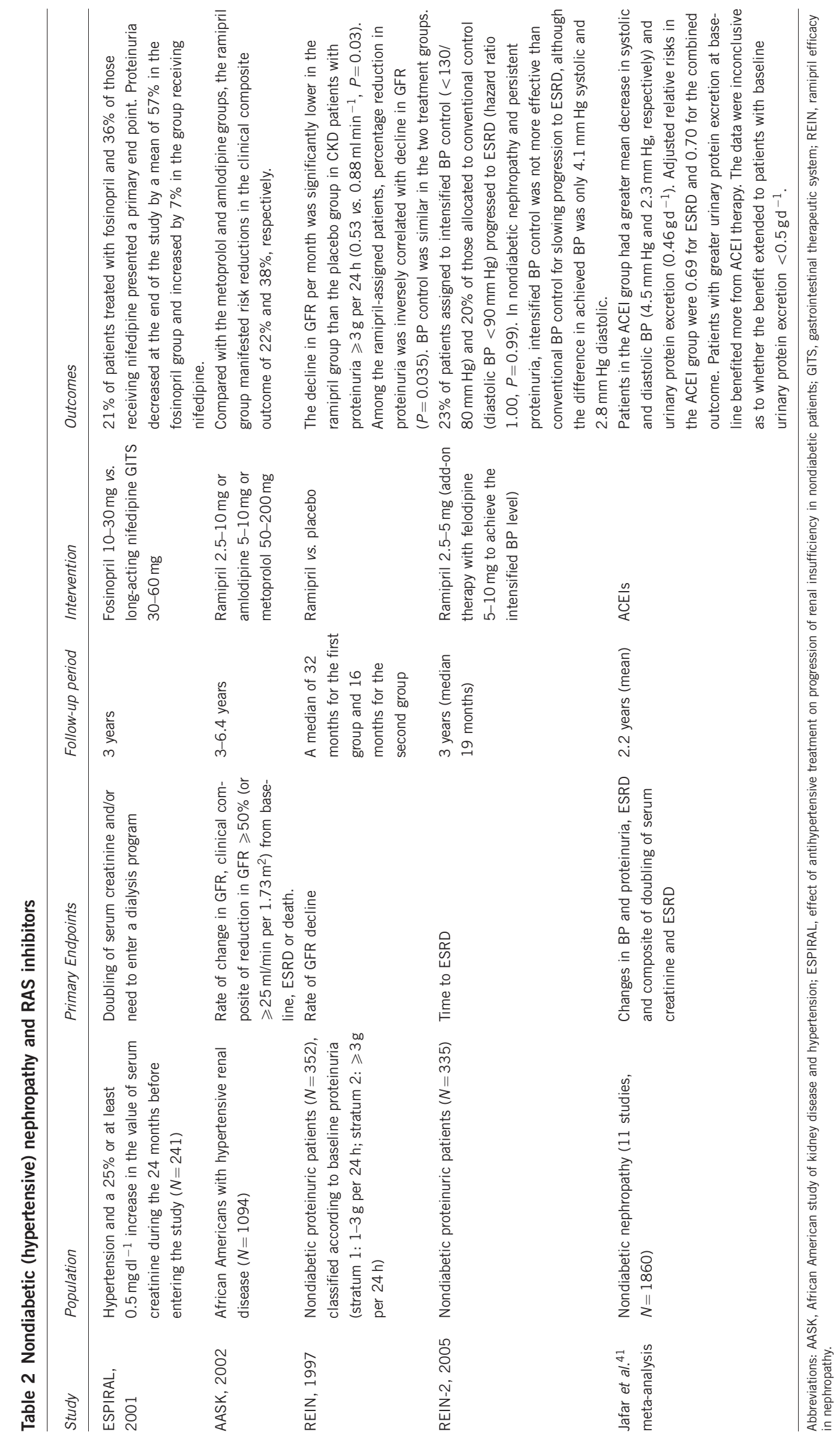


GFR and potassium excretion, thus renal function and serum potassium levels should be monitored carefully.

The meta-analysis conducted by Jafar et al., ${ }^{41}$ which included 11 studies with a total of 1860 nondiabetic patients with renal disease, confirms the benefits of ACEIs in renal function protection, especially in patients with greater urinary protein excretion at baseline. To the same extent, Kent et al. ${ }^{42}$ suggest that there is no preferential benefit of ACEIs in nondiabetic patients with protein excretion $<500 \mathrm{mg}$ per day. In addition, the most recent meta-analysis of Sharma et al. ${ }^{43}$ demonstrates the lack of evidence of the effectiveness of ACEIs or ARBs in patients with stage 1-3 CKD who do not have diabetes mellitus. No published studies comparing ARBs with placebo were identified. It is notable that KDOQI hypertension guidelines do not have a preferred agent in nondiabetic CKD with spot urine total protein to creatinine $<200 \mathrm{mg} \mathrm{g}^{-1}$. $^{12}$

\section{Combination treatment}

As the findings of previous studies depicted the possibility of improved renal outcomes with dual RAS inhibition, newer trials examined this hypothesis. To date, the main study is the Ongoing Telmisartan Alone and in Combination with Ramipril Global Endpoint Trial (ONTARGET ${ }^{44}$ ), which investigated the effect of telmisartan plus ramipril compared with monotherapies in 25620 patients with established atherosclerotic vascular disease or with diabetes with end-organ damage and found a reduction in albuminuria in telmisartan $(P=0.004)$ and combination therapy groups $(P=0.001)$ that persisted during the follow-up period (median 56 months). Notably, most patients had a normal baseline renal function and few (4\%) exhibited overt proteinuria, which resulted in a very limited number of the renal end points that were significantly more frequent in combination therapy group $(P=0.038)$. In addition, adverse events like acute dialysis and hyperkalemia were more often in combination therapy $(P=0.02)$. An ongoing trial, VA NEPHRON-D, is expected to clarify whether combination therapy is beneficial or not. In this trial, losartan plus lisinopril combination compared with losartan alone is examined in 1850 patients with type 2 diabetes and overt proteinuria for a period of $2-5$ years. The study is estimated to complete in $2014 .{ }^{45}$ Current evidence does not prove combination therapy to be superior. Conversely, it may increase adverse outcomes.

Recent ESH-ESC ${ }^{10}$ and $\mathrm{JNC}^{11}$ guidelines, based on the results of clinical trials and meta-analyses that clearly demonstrate the beneficial role of RAS-inhibitors on renal and cardiac protection, suggest ACEIs and ARBs as first choice for hypertension in patients with kidney disease, unless contraindicated, as it is in bilateral renal stenosis and pregnancy.

However, the majority of studies did not include patients above 70 years old. In addition, older patients with CKD are less likely to have proteinuria, ${ }^{46}$ thus, as discussed above, would not benefit from RAS inhibition. ${ }^{42}$ Moreover, elderly people are more prone to acute renal injury and hyperkalemia, due to a number of structural and functional changes characteristic of the ageing kidney. ${ }^{47}$ The above findings question the use of the RAS inhibition in the elderly. ${ }^{48}$

\section{CALCIUM CHANNEL BLOCKERS}

CCBs are classified in dihydropyridines, like amlodipine, felodipine and nifedipine, which are mainly peripheral vasodilators, and in nondihydropyridines, like verapamil and diltiazem, which have adjunctive cardioprotective effect, as they decrease heart rate and myocardial contractility. First generation CCBs, like nifedipine, act exclusively on L-type calcium channels, and predominantly dilate afferent arterioles with the danger of glomerular hypertension and subsequent harm of the renal microcirculation. A good control of systemic BP, however, does not eliminate this risk. On the contrary, novel calcium antagonists, including efonidipine, ${ }^{49,50}$ manidipine ${ }^{51,52}$ and benidipine, ${ }^{53}$ which are predominantly licensed in Asian countries, block both L- and T-type calcium channels and elicit vasodilation of afferent and efferent arterioles. Moreover, T-type CCBs have been shown to inhibit renin release and inflammatory processes ${ }^{54}$ and attenuate oxidative stress. ${ }^{53}$ In support of these notions, Abe et al. ${ }^{55}$ and Ohta et al. ${ }^{56}$ showed that benidipine exerted antiproteinuric effect to a greater extent than amlodipine in hypertensive patients that was independent of the drug's antihypertensive effects.

Larger studies have shown the beneficial effect of CCBs on renal outcomes. Intervention as a Goal in Hypertension Treatment (INSIGHT) study showed a small but significant GFR decline in the diuretic group compared with nifedipine, supporting the notion of a greater renoprotective effect of nifedipine. ${ }^{57}$ Likewise, a post-hoc analysis of Systolic Hypertension in Europe (SYST-EUR) trial for renal outcomes reported that the incidence of mild renal dysfunction decreased by $64 \%(P=0.04)$ in patients receiving active therapy with nitrendipine and the incidence of proteinuria decreased by $33 \%$ $(P=0.03)$. Active treatment reduced the risk of proteinuria more in diabetic $(71 \%)$ than in nondiabetic patients $(20 \%)$ and decreased significantly serum creatinine in patients with baseline proteinuria $(P<0.001) .{ }^{58}$ Unlike the above, a post-hoc analysis of ALLHAT trial for renal outcomes showed that in hypertensive patients with reduced GFR, there were no statistically significant differences between amlodipine, lisinopril and chlorthalidone in reducing the rate of development of ESRD or a $50 \%$ or greater decrement in GFR. ${ }^{59}$ Moreover, AASK study demonstrated less renoprotection and increase in proteinuria with amlodipine compared with ramipril $(P<0.001){ }^{36}$

Several studies to date indicate that non-dihydropyridine CCBs decrease proteinuria in a greater extent than dihydropyridine CCBs in hypertensive patients, with or without diabetes. A systematic review of 28 randomized clinical trials was conducted by Bakris et al. ${ }^{60}$ to assess the differential effects of these two subclasses on proteinuria, in hypertensive patients with proteinuria. The study revealed a $2 \%$ increase in proteinuria for dihydropyridine CCBs and a $30 \%$ reduction for non-dihydropyridine CCBs. On the other hand, in Bergamo Nephrologic Diabetes Complications Trial (BENEDICT), which involved hypertensive patients with type 2 diabetes, albeit verapamil plus trandolapril combination therapy was shown to reduce microalbuminuria, adding verapamil did not improve the renoprotective effects of RAS inhibition with trandolapril. ${ }^{16,61}$ In addition, Verapamil Versus Amlodipine in Nondiabetic Nephropathies Treated with Trandolapril (VVANNTT) trial, which involved patients with nondiabetic proteinuric nephropathy treated with an ACEI, showed that the addition of a non-dihydropyridine or a dihydropyridine CCB did not significantly increase its antiproteinuric effect $^{62}$ (Table 3 ).

$\mathrm{CCBs}$ have a great heterogeneity and as a result, their effect to kidney disease progression is variable. Notably, short-acting formulations may increase sympathetic activity and activate RAS, due to acute peripheral vasodilation, wheras long-acting CCB agents might be beneficial in $\mathrm{CKD}$ patients that belong to non-dippers, whose nocturnal decrease of mean $\mathrm{BP}$ is $<10 \%$ of daytime $\mathrm{BP}^{63}$

\section{$\beta$-BLOCKERS}

In patients with chronic renal failure, afferent signals from diseased kidneys to integrative structures in the brain result in activation of sympathetic outflow. ${ }^{64}$ In addition, reduced expression and secretion 


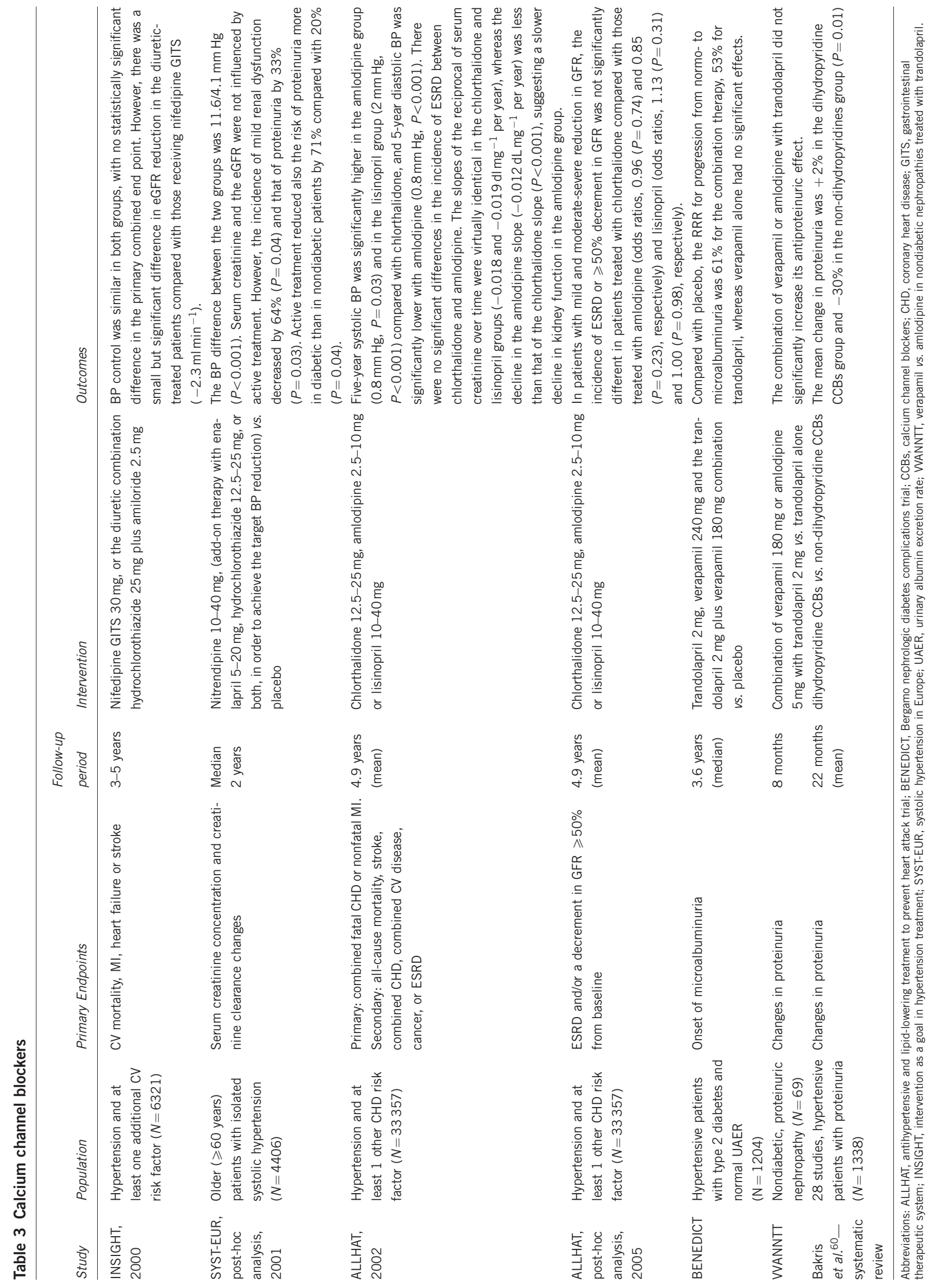


of renalase, an enzyme that metabolizes catecholamines and is predominantly expressed in glomeruli and proximal tubules, may have a causative role in increased plasma catecholamine levels. ${ }^{65}$ Sympathetic nervous system acts on the kidney through its $\beta-1, \beta-2$ and $\alpha-1$ receptors and affects the vasomotor tone of renal arterioles, in order to maintain a constant glomerular filtration. ${ }^{66} \beta-1$ receptors cause renin release and increase in cardiac output, $\beta$-2 receptors induce vasodilation and increase glycogenolysis, whereas $\alpha-1$ receptors induce vasoconstriction. ${ }^{66}$ In the case of $\mathrm{CKD}$, the efferent arterioles are constricted more than the afferents, thereby increasing intraglomerular pressure.

Propanolol, a classic agent of this group, together with carvedilol and labetalol belong to non-selective $\beta$-blockers, as they exert blocking action both on $\beta-1$ and $\beta-2$ receptors. $\beta$-1-selective or cardio-selective blockers include metoprolol, atenolol and nebivolol. Carvedilol and labetalol mediate vasodilation through additional blockade of the $\alpha$-1-adrenergic receptors. ${ }^{67}$ Nebivolol may also exert vasodilation via stimulation of nitric oxide. ${ }^{68}$ In addition, carvedilol and nebivolol have antioxidant effect ${ }^{69-73}$ and a safer metabolic profile. $^{74-77}$ Thus, newer $\beta$-blockers carvedilol and nebivolol are more beneficial. However, $\beta$-blockers are underused and this is in large part due to tolerability of these agents. ${ }^{78}$ Traditional $\beta$-blockers, like propranolol, atenolol and metoprolol, reduce GFR and renal blood flow, ${ }^{79}$ as a result of the decreased cardiac output they cause and the elevation of peripheral vascular resistance due to unblocked $\alpha-1$ receptors. The USRDS Dialysis Morbidity and Mortality Study found that only $20 \%$ of chronic dialysis patients were receiving $\beta$-blocker therapy. ${ }^{80} \mathrm{~A}$ similar trend occurs in the predialysis patients (with mild to moderate renal insufficiency). ${ }^{81}$

When it comes to comparing $\beta$-blockers with other antihypertensive drugs, in terms of renal protection, unfortunately, a few studies on long-term renal outcomes are available. AASK trial compared ramipril with metoprolol and amlodipine and showed that the first one reduced progression of hypertensive renal disease to a greater extent than either of the two other drugs; however, patients in metoprolol group had significantly lower ESRD or death rate comparing with those receiving amlodipine. ${ }^{36}$ A major metaanalysis was conducted in 2005 that included 13 trials comparing a $\beta$-blocker with active treatment and seven studies comparing a $\beta$-blocker with placebo. This meta-analysis showed $16 \%$ increase of strokes and $3 \%$ of total mortality in $\beta$-blockers group compared with other antihypertensive drugs. ${ }^{82}$ In the light of these results $\beta$-blockers use as first choice antihypertensive drugs was challenged. ${ }^{83}$

However, the importance of sympathetic nervous system activation in hypertension, CKD pathogenesis and the increased cardiovascular morbidity and mortality seen in CKD patients, justify $\beta$-blockers, especially the newer vasodilating ones, as an adjunctive antihypertensive treatment in CKD that can provide cardiorenal protection. ${ }^{84}$

\section{DIURETICS}

Extracellular volume expansion due to fluid and sodium retention is a substantial contributing factor to hypertension seen in chronic renal failure. Diuretics are therefore a useful tool to manage volume overload and to achieve strict blood pressure control in these patients. ${ }^{85,86}$ Thiazide diuretics, especially chlorthalidone, have a longer antihypertensive effect than the loop diuretics. Loop diuretics are less effective in patients with normal renal function, unless they are given in multiple daily doses. However, as thiazide diuretics are less effective at low levels of GFR, a loop diuretic is preferred in patients with more advanced CKD $\left(\mathrm{GFR}<30 \mathrm{ml} \mathrm{min}^{-1}\right)$, as well as in acute renal failure. ${ }^{12,87}$
Several studies have shown the substantial role of diuretics in CKD. De Nicola et al. ${ }^{88}$ assessed control rates and treatment of hypertension in 1200 patients with CKD from Italy and found that, although $70 \%$ received multidrug antihypertensive therapy including RAS inhibitors, BP target was achieved in only $12 \%$ of patients. Notably, diuretic treatment was prescribed in a minority of patients (37\%) and at insufficient doses in half the cases. Researchers concluded that the main barrier to guideline implementation was possibly the inadequate treatment of extracellular volume expansion. Moreover, Abe et al. ${ }^{85}$ proposed that a low dose of hydrochlorothiazide should be administered to those patients in whom BP is not controlled well by intensive RAS inhibition therapy using the maximum recommended doses of ARBs and ACEIs. In this study, hydrochlorothiazide was shown to have a renoprotective effect in hypertensive patients with stage 3-4 CKD, as it significantly decreased BP and urinary protein/creatinine ratio. In addition, ALLHAT trial showed that chlorthalidone reduced systolic BP more than either amlodipine or lisinopril, ${ }^{7}$ while a post-hoc analysis found no statistically significant differences in ESRD incidence rate between the three treatment groups. ${ }^{59}$

Diuretic use as monotherapy is controversial. Although European ${ }^{10}$ and $\mathrm{US}^{11}$ guidelines on hypertension recommend the use of thiazide diuretics as first-line therapy, ${ }^{89}$ some researchers have a different opinion. ${ }^{90}$ Arguments are based on the fact that diuretics induce RAS stimulation, as well as metabolic alterations in glucose and lipids, ${ }^{91,92}$ that may have negative impact on cardiovascular outcomes. The results of numerous large intervention trials support the concept that long-term therapy with diuretics, especially when diuretics are combined with $\beta$-blockers, reduce glucose tolerance and increases new-onset diabetes risk. Examples of such studies are the Antihypertensive Treatment and Lipid Profile in a North of Sweden Efficacy Evaluation trial (ALPINE) ${ }^{93}$ INSIGHT trial ${ }^{57}$ and Captopril Prevention Project (CAPPP) trial. ${ }^{94}$ Furthermore, despite increasing diuretic therapy in the US, Hawkins and Houston ${ }^{95}$ also observed increasing incidence of ESRD and examined the possibility that these two parameters are related to each other. The study synthesized data from different national databases for the decade 1990-2001 with data fusion technique and the results showed a positive correlation between changes in the use of diuretics and the increase the occurrence of ESRD, with a time lag of 2 years.

The majority of studies so far have limited duration and middle to long-term diuretic efficacy in renal protection has not been sufficiently assessed. However, control of volume retention remains the most important key to hypertension treatment in patients with chronic renal failure and, for the most part, cannot be adequately regulated without the use of a diuretic.

\section{ALDOSTERONE RECEPTOR BLOCKERS}

Accumulating evidence suggests that aldosterone per se is an important mediator of renal injury, while elevated levels have been found in CKD.96,97 Aldosterone may induce inflammation and fibrosis in the kidney by stimulating plasminogen activator inhibitor-1 expression, ${ }^{98}$ generating reactive oxygen species and transforming growth factor- $\beta$ expression. ${ }^{99}$ Albeit ACEIs and ARBs suppress RAS, their action is not enough to control plasma aldosterone levels, owing to aldosterone escape during long-term blockade of the renin-angiotensin-aldosterone system. ${ }^{100}$ As a result, aldosterone receptor blockers therapy could enhance antihypertensive treatment. $^{101}$

Aldosterone antagonists are classified in the non-selective, like spironolactone, and in the newer selective antagonists, like 
eplerenone. Both substances have been proved to reduce albuminuria in patients with diabetic nephropathy. Rossing et al. ${ }^{102}$ have shown that $25 \mathrm{mg}$ of spironolactone, when added to maximum ACEI or ARB treatment, resulted in $33 \%$ reduction of albuminuria $(P<0.001)$ in patients with type 2 diabetes and nephropathy. In addition, Epstein et al. ${ }^{103}$ showed that adding 50-100 mg of eplerenone in ACEI therapy in patients with type 2 diabetes and nephropathy resulted in $41 \%$ reduction of albuminuria $(P<0.001)$ comparing with placebo group. Conversely, hyperkalemia, an important side effect of aldosterone antagonist therapy, can be aggravated by concurrent renal insufficiency, diabetes mellitus, severe heart failure, old age and other potassium-sparing drugs. Aldosterone antagonists are not recommended when serum creatinine is $>2.5 \mathrm{mg} \mathrm{dl}^{-1}$ or creatinine clearance is $<30 \mathrm{ml} \mathrm{min}^{-1}$ or serum potassium is $>5 \mathrm{mmoll}^{-1}$. 11,104 Unfortunately, there are not yet studies comparing non-selective to selective aldosterone antagonists, neither studies evaluating the long-term effects of aldosterone antagonists combined to other RAS inhibitors, in terms of kidney function. Therefore, aldosterone antagonists cannot be yet recommended as a routine additional therapy in patients with CKD.

\section{$\alpha$-BLOCKERS}

Alpha1-adrenergic blockers, including doxazosin, terazosin and prazosin, inhibit vasoconstriction that is induced by sympathetic nervous system through noradrenaline and cause vasodilation, reduction of peripheral resistances and BP decrease. To date, studies have not shown a special benefit of these drugs in cardiovascular and renal protection. The ALLHAT study showed that cardiovascular and renal outcomes were not significantly reduced in $\alpha$-blocker group (doxazosin) comparing with diuretic group in patients with metabolic syndrome, including those without diabetes mellitus $(\mathrm{RR}=1.18) .{ }^{105} \alpha$-blockers lack potent antihypertensive effect, especially when used as monotherapy, but they are usually given in combination with other antihypertensive drugs in CKD patients that have resistant hypertension. ${ }^{106}$ In addition, they are of benefit in men with symptomatic benign prostatic hyperplasia. Their most common adverse effect is sudden occurrence of orthostatic hypotension after first dose, which can be avoided if treatment is initialized in low dose. Other known adverse effects, like headache, dry mouth and weakness, have been eliminated with newer components.

\section{CENTRALLY ACTING ANTIHYPERTENSIVES}

Centrally acting drugs, like clonidine, a-methyldopa, guanfacine and the newer moxonidine, cross the blood-brain barrier and act centrally by activating $\alpha$-2-adrenergic receptors in the vasomotor center in the brain stem and hypothalamus, resulting in reduction of peripheral sympathetic tone and hence vasodilation and a fall in BP, heart rate and cardiac output. ${ }^{107}$ No adverse metabolic effects have been mentioned, but a numerous of other side effects, like dry mouth, fatigue, drowsiness and sedation. Cessation of therapy with clonidine, and to a lesser extent with methyldopa and guanfacine, may result in a severe withdrawal syndrome characterized by restlessness, sweating, anxiety, tremor, palpitations, headache and a rebound rise in BP. Moxonidine and rilmenidine (not available in the United States), the newer substances of this group, have a more selective action on I1-imidazoline receptors, located in the nucleus reticularis lateralis, and therefore their side-effect profile is more favorable. ${ }^{108}$ There is a lack of studies on the impact of centrally acting antihypertensives on $\mathrm{CKD}$, however, there is a long experience especially with clonidine use and these agents may be added to an existing regimen in cases of resistant hypertension.

\section{RENIN INHIBITORS}

The most recent agents of renin-angiotensin-aldosterone system inhibitors are renin inhibitors. The blockade of renin is a very attractive idea, as the interaction of renin with its physiological substrate angiotensinogen is the rate-limiting step in the reninangiotensin-aldosterone system cascade. The first commercially available orally active renin inhibitor is aliskiren. ${ }^{109}$ Aliskiren acts by binding to the active site of renin, thereby inhibiting catalytic activity, and reduces angiotensin II levels and plasma renin activity without stimulating compensatory increases in plasma renin activity, angiotensin I and angiotensin II, as seen with ACEIs and ARBs. ${ }^{110}$ In addition, it is well tolerated and effective in lowering BP in both the general population of hypertensive patients and specific patient groups, such as obese people. ${ }^{111}$ Studies in animal models have shown that aliskiren has renoprotective, cardioprotective and antiatherosclerotic properties, which are independent of BP reduction. ${ }^{111}$

In terms of proteinuria reduction in diabetic patients, Aliskiren in the Evaluation of Proteinuria in Diabetes (AVOID) trial has shown positive results. The study compared the combination of aliskiren/ losartan with losartan as monotherapy in 599 hypertensive patients with type 2 diabetes and nephropathy for a period of 6 months. According to the results, proteinuria in the combined therapy group was reduced by $20 \%$ more than in the control group, while adverse events were similar in both treatment groups. ${ }^{112}$ However, the longer Aliskiren Trial in Type 2 Diabetes Using Cardio-Renal Endpoints (ALTITUDE) ${ }^{113}$ was early terminated when an interim review of data showed an increased risk for non-fatal stroke, renal complications, hyperkalemia and hypotension in patients taking aliskiren in combination with an ACEI or an ARB after 18-24 months. Further studies to evaluate the renoprotective effect of aliskiren are required.

\section{ENDOTHELIN-1 RECEPTOR ANTAGONISTS}

Endothelin-1 is a strong vasoconstrictor peptide, 30-50 times more potent than equimolar quantities of norepinephrine and angiotensin II. ${ }^{114}$ It is notable that the medulla of the kidney has the highest concentration of endothelin receptors in the body, while in the cortex $70 \%$ of receptors are type B. ${ }^{115}$ Activation of ET-B receptor results in vasodilation through the release of nitric oxide, prostacyclin, atrial natriuretic peptide and adrenomeduline. ${ }^{116,117}$ Moreover, it induces natriuresis and diuresis ${ }^{18,119}$ and participates in the clearance of endothelin-1. ${ }^{120}$ In contrast, ET-A receptors cause vasoconstriction and inflammatory reactions. A double-blind randomized multicenter study of Weber et al., ${ }^{121}$ which included 379 patients with resistant hypertension, showed that the substance darusentan, a selective ET-A receptor antagonist, offered additional reduction of BP. In addition, Wenzel et al. ${ }^{122}$ followed up 286 patients with diabetic nephropathy, macroalbuminuria and hypertension for 12 weeks, and showed a significant decrease in albuminuria in the group where the substance avosentan, a non-selective antagonist, was added in the already given treatment with ACEIs or ARBs. In both studies, the main side effect was fluid retention, while a dose-dependent hepatotoxicity was also reported. Although endothelin receptor antagonists have already been approved for the treatment of pulmonary hypertension, ${ }^{123}$ the available studies on arterial hypertension and CKD are still inefficient. ${ }^{124}$

\section{CONCLUSIONS}

It is clear that the goal of antihypertensive therapy should be to obtain optimal BP control. A variety of BP lowering agents is available for clinical use. Usually, a combination of two or more antihypertensive drugs is required in order to control hypertension. In fact, 
antihypertensive treatment is individualized to each patient depending on the tolerance, compliance and specific clinical features.

ACEIs and ARBs have been undoubtedly studied the most. Their ability to induce dilation of efferent arterioles in renal glomerulus, resulting in reduced intraglomerular pressure, and to inhibit proinflammatory and proliferative actions exerted by angiotensin II, makes them the most commonly used drugs in CKD patients, particularly in those with diabetes, as they have neutral metabolic effects and they have been shown to significantly reduce proteinuria. Less data are available for the long-term effects of other agents on CKD. CCBs have been proved to control BP effectively, $\beta$-blockers to regulate sympathetic nervous system overactivity observed in chronic renal failure and diuretics to control expansion of intravascular volume caused by fluid retention. Notably, $\beta$-blockers reduce insulin sensitivity, except for some newer substances, and therefore they should be avoided in patients with diabetes or impaired glucose tolerance. Moreover, CCBs may increase proteinuria, unless BP is well controlled, because they dilate the afferent arteriole and increase intraglomerular pressure. Clinical studies have shown that especially diltiazem and verapamil appear to have greater renoprotective role than dihydropyridines.

To achieve the desired levels of BP, an ACEI or ARB can be combined with a thiazide diuretic or loop diuretic, and, if necessary, a CCB or a $\beta$-blocker can be added. The combination of ACEIs with ARBs appears to reduce further the proteinuria in CKD. However, a significant risk for hyperkalemia and acute renal failure has been attributed to this combination. Continuous research has found new substances that might contribute to optimal BP control, such as renin inhibitors, the newest RAS blockers, and inhibitors of endothelin-1, which have beneficial effects when combined with ACEIs.

\section{CONFLICT OF INTEREST}

The authors declare no conflict of interest.

1 Levey AS, Coresh J, Balk E, Kausz AT, Levin A, Steffes MW, Hogg RJ, Perrone RD, Lau J, Eknoyan G. National Kidney Foundation practice guidelines for chronic kidney disease: evaluation, classification, and stratification. Ann Intern Med 2003; 139: 137-147

2 United States Renal Data System, National Institutes of Health, National Institute of Diabetes and Digestive and Kidney Diseases. USRDS 2011 Annual Data Report: Atlas of Chronic Kidney Disease and End-Stage Renal Disease in the United States. United States Renal Data System, National Institutes of Health, National Institute of Diabetes and Digestive and Kidney Diseases, Bethesda, MD, 2011.

3 Academic Medical Center, Department of Medical Informatics. ERA-EDTA Registry: ERA-EDTA Registry Annual Report 2009. Academic Medical Center, Department of Medical Informatics, Amsterdam, The Netherlands, 2011.

4 Coresh J, Wei GL, McQuillan G, Brancati FL, Levey AS, Jones C, Klag MJ. Prevalence of high blood pressure and elevated serum creatinine level in the United States: findings from the third National Health and Nutrition Examination Survey (19881994). Arch Intern Med 2001; 161: 1207-1216.

5 Peterson JC, Adler S, Burkart JM, Greene T, Hebert LA, Hunsicker LG, King AJ, Klahr S, Massry SG, Seifter JL. Blood pressure control, proteinuria, and the progression of renal disease. The Modification of Diet in Renal Disease Study. Ann Intern Med 1995; 123: 754-762.

6 Klag MJ, Whelton PK, Randall BL, Neaton JD, Brancati FL, Ford CE, Shulman NB, Stamler J. Blood pressure and end-stage renal disease in men. N Engl J Med 1996; 334: 13-18.

7 ALLHAT Officers and Coordinators for the ALLHAT Collaborative Research Group. Major outcomes in high-risk hypertensive patients randomized to angiotensinconverting enzyme inhibitor or calcium channel blocker vs diuretic: The Antihypertensive and Lipid-Lowering Treatment to Prevent Heart Attack Trial (ALLHAT). JAMA 2002; 288: 2981-2997.

8 Rahman M, Ford CE, Cutler JA, Davis BR, Piller LB, Whelton PK, Wright Jr JT, Barzilay JI, Brown CD, Colon Sr PJ, Fine LJ, Grimm Jr RH, Gupta AK, Baimbridge C, Haywood LJ, Henriquez MA, Ilamaythi E, Oparil S, Preston R. Long-Term Renal and Cardiovascular Outcomes in Antihypertensive and Lipid-Lowering Treatment to Prevent Heart Attack Trial (ALLHAT) Participants by Baseline Estimated GFR. Clin J Am Soc Nephrol 2012; 7: 989-1002.
9 Staessen JA, Wang JG, Thijs L. Cardiovascular prevention and blood pressure reduction: a quantitative overview updated until 1 March 2003. J Hypertens 2003; 21: 1055-1076.

10 Mancia G, De Backer G, Dominiczak A, Cifkova R, Fagard R, Germano G, Grassi G, Heagerty AM, Kjeldsen SE, Laurent S, Narkiewicz K, Ruilope L, Rynkiewicz A, Schmieder RE, Boudier HA, Zanchetti A, Vahanian A, Camm J, De Caterina R, Dean V, Dickstein K, Filippatos G, Funck-Brentano C, Hellemans I, Kristensen SD, McGregor K, Sechtem U, Silber S, Tendera M, Widimsky P, Zamorano JL, Erdine S, Kiowski W, Agabiti-Rosei E, Ambrosioni E, Lindholm LH, Viigimaa M, Adamopoulos S, Bertomeu V, Clement D, Farsang C, Gaita D, Lip G, Mallion JM, Manolis AJ, Nilsson PM, O'Brien E, Ponikowski P, Redon J, Ruschitzka F, Tamargo J, van Zwieten PA, Waeber B, Williams B. 2007 Guidelines for the Management of Arterial Hypertension: The Task Force for the Management of Arterial Hypertension of the European Society of Hypertension (ESH) and of the European Society of Cardiology (ESC). J Hypertens 2007; 25: 1105-1187.

11 Chobanian AV, Bakris GL, Black HR, Cushman WC, Green LA, Izzo Jr JL, Jones DW, Materson BJ, Oparil S, Wright Jr JT, Roccella EJ. The Seventh Report of the Joint National Committee on Prevention, Detection, Evaluation, and Treatment of High Blood Pressure: the JNC 7 report. JAMA 2003; 289: 2560-2572.

$12 \mathrm{~K} / \mathrm{DOQI}$. K/DOQI clinical practice guidelines on hypertension and antihypertensive agents in chronic kidney disease. Am J Kidney Dis 2004; 43: S1-S290.

13 Mancia G, Laurent S, Agabiti-Rosei E, Ambrosioni E, Burnier M, Caulfield MJ, Cifkova R, Clement D, Coca A, Dominiczak A, Erdine S, Fagard R, Farsang C, Grassi G, Haller H, Heagerty A, Kjeldsen SE, Kiowski W, Mallion JM, Manolis A, Narkiewicz K, Nilsson P, Olsen MH, Rahn KH, Redon J, Rodicio J, Ruilope L, Schmieder RE, StruijkerBoudier HA, van Zwieten PA, Viigimaa M, Zanchetti A. Reappraisal of European guidelines on hypertension management: a European Society of Hypertension Task Force document. J Hypertens 2009; 27: 2121-2158.

14 Upadhyay A, Earley A, Haynes SM, Uhlig K. Systematic review: blood pressure target in chronic kidney disease and proteinuria as an effect modifier. Ann Intern Med 2011; 154: 541-548.

15 Brenner BM, Cooper ME, de Zeeuw D, Keane WF, Mitch WE, Parving HH, Remuzzi G, Snapinn SM, Zhang Z, Shahinfar S. Effects of losartan on renal and cardiovascular outcomes in patients with type 2 diabetes and nephropathy. N Eng/ J Med 2001; 345: 861-869.

16 Ruggenenti P, Perna A, Ganeva M, Ene-lordache B, Remuzzi G. Impact of blood pressure control and angiotensin-converting enzyme inhibitor therapy on new-onset microalbuminuria in type 2 diabetes: a post hoc analysis of the BENEDICT trial. J Am Soc Nephrol 2006; 17: 3472-3481.

17 Halbesma N, Kuiken DS, Brantsma AH, Bakker SJ, Wetzels JF, De Zeeuw D, De Jong $\mathrm{PE}$, Gansevoort RT. Macroalbuminuria is a better risk marker than low estimated GFR to identify individuals at risk for accelerated GFR loss in population screening. J Am Soc Nephrol 2006; 17: 2582-2590.

18 Halbesma N, Jansen DF, Stolk RP, De Jong PE, Gansevoort RT. Changes in renal risk factors versus renal function outcome during follow-up in a population-based cohort study. Nephrol Dial Transplant 2010; 25: 1846-1853.

19 Wolf G, Ziyadeh FN. Cellular and molecular mechanisms of proteinuria in diabetic nephropathy. Nephron Physiol 2007; 106: 26-31.

20 Parving HH, Andersen AR, Smidt UM, Svendsen PA. Early aggressive antihypertensive treatment reduces rate of decline in kidney function in diabetic nephropathy. Lancet 1983; 1: 1175-1179.

21 Sraer JD, Kanfer A, Rondeau E, Lacave R. Role of the renin-angiotensin system in the regulation of glomerular filtration. J Cardiovasc Pharmacol 1989; 14(Suppl 4): S21-S25.

22 Dielis AW, Smid M, Spronk HM, Hamulyak K, Kroon AA, ten CH, de Leeuw PW. The prothrombotic paradox of hypertension: role of the renin-angiotensin and kallikreinkinin systems. Hypertension 2005; 46: 1236-1242.

23 Lewis EJ, Hunsicker LG, Bain RP, Rohde RD. The effect of angiotensin-convertingenzyme inhibition on diabetic nephropathy. The Collaborative Study Group. N Eng/ J Med 1993; 329: 1456-1462.

24 Heart Outcomes Prevention Evaluation Study Investigators. Effects of ramipril on cardiovascular and microvascular outcomes in people with diabetes mellitus: results of the HOPE study and MICRO-HOPE substudy. Lancet 2000; 355: 253-259.

25 Viberti G. Wheeldon NM. Microalbuminuria reduction with valsartan in patients with type 2 diabetes mellitus: a blood pressure-independent effect. Circulation 2002; 106: 672-678.

26 Parving $\mathrm{HH}$, Lehnert H, Brochner-Mortensen J, Gomis R, Andersen S, Arner P. The effect of irbesartan on the development of diabetic nephropathy in patients with type 2 diabetes. N Engl J Med 2001; 345: 870-878.

27 Ravera M, Ratto E, Vettoretti S, Parodi D, Deferrari G. Prevention and treatment of diabetic nephropathy: the program for irbesartan mortality and morbidity evaluation. J Am Soc Nephrol 2005; 16(Suppl 1): S48-S52.

28 Lewis EJ, Hunsicker LG, Clarke WR, Berl T, Pohl MA, Lewis JB, Ritz E, Atkins RC, Rohde R, Raz I. Renoprotective effect of the angiotensin-receptor antagonist irbesartan in patients with nephropathy due to type 2 diabetes. $N$ Eng/ J Med 2001; 345: 851-860.

29 Siebenhofer A, Plank J, Horvath K, Berghold A, Sutton AJ, Sommer R, Pieber TR. Angiotensin receptor blockers as anti-hypertensive treatment for patients with diabetes mellitus: meta-analysis of controlled double-blind randomized trials. Diabet Med 2004; 21: 18-25.

30 Haller H, Ito S, Izzo Jr JL, Januszewicz A, Katayama S, Menne J, Mimran A, Rabelink TJ, Ritz E, Ruilope LM, Rump LC, Viberti G. Olmesartan for the delay or prevention of microalbuminuria in type 2 diabetes. N Engl J Med 2011; 364: 907-917. 
31 Menne J, Izzo Jr JL, Ito S, Januszewicz A, Katayama S, Chatzykirkou C, Mimran A, Rabelink TJ, Ritz E, Ruilope LM, Rump LC, Viberti G, Haller H. Prevention of microalbuminuria in patients with type 2 diabetes and hypertension. J Hypertens 2012; 30: 811-818.

32 Rippin J, Bain SC, Barnett AH. Rationale and design of diabetics exposed to telmisartan and enalapril (DETAIL) study. J Diabetes Complications 2002; 16: 195-200.

33 Barnett A. Preventing renal complications in type 2 diabetes: results of the diabetics exposed to telmisartan and enalapril trial. J Am Soc Nephrol 2006; 17 S132-S135.

34 Barnett AH, Bain SC, Bouter P, Karlberg B, Madsbad S, Jervell J, Mustonen J. Angiotensin-receptor blockade versus converting-enzyme inhibition in type 2 diabetes and nephropathy. N Engl J Med 2004; 351: 1952-1961.

35 Marin R, Ruilope LM, Aljama P, Aranda P, Segura J, Diez J. A random comparison of fosinopril and nifedipine GITS in patients with primary renal disease. $J$ Hypertens 2001; 19: 1871-1876.

36 Wright Jr JT, Bakris G, Greene T, Agodoa LY, Appel LJ, Charleston J, Cheek D, Douglas-Baltimore JG, Gassman J, Glassock R, Hebert L, Jamerson K, Lewis J, Phillips RA, Toto RD, Middleton JP, Rostand SG. Effect of blood pressure lowering and antihypertensive drug class on progression of hypertensive kidney disease: results from the AASK trial. JAMA 2002; 288: 2421-2431.

37 The GISEN Group (Gruppo Italiano di Studi Epidemiologici in Nefrologia). Randomised placebo-controlled trial of effect of ramipril on decline in glomerular filtration rate and risk of terminal renal failure in proteinuric, non-diabetic nephropathy. Lancet 1997; 349: 1857-1863.

38 Ruggenenti P, Perna A, Loriga G, Ganeva M, Ene-lordache B, Turturro M, Lesti M, Perticucci E, Chakarski IN, Leonardis D, Garini G, Sessa A, Basile C, Alpa M, Scanziani R, Sorba G, Zoccali C, Remuzzi G. Blood-pressure control for renoprotection in patients with non-diabetic chronic renal disease (REIN-2): multicentre, randomised controlled trial. Lancet 2005; 365: 939-946.

39 Ruggenenti P, Perna A, Remuzzi G. ACE inhibitors to prevent end-stage renal disease: when to start and why possibly never to stop: a post hoc analysis of the REIN tria results. Ramipril Efficacy in Nephropathy. J Am Soc Nephrol 2001; 12: 2832-2837.

40 Hou FF, Zhang X, Zhang GH, Xie D, Chen PY, Zhang WR, Jiang JP, Liang M, Wang GB, Liu ZR, Geng RW. Efficacy and safety of benazepril for advanced chronic renal insufficiency. N Engl J Med 2006; 354: 131-140.

41 Jafar $\mathrm{TH}$, Schmid $\mathrm{CH}$, Landa M, Giatras I, Toto R, Remuzzi G, Maschio G, Brenner BM, Kamper A, Zucchelli P, Becker G, Himmelmann A, Bannister K, Landais P, Shahinfar S, de Jong PE, de Zeeuw D, Lau J, Levey AS. Angiotensin-converting enzyme inhibitors and progression of nondiabetic renal disease. A meta-analysis of patient-level data. Ann Intern Med 2001; 135: 73-87.

42 Kent DM, Jafar TH, Hayward RA, Tighiouart H, Landa M, de Jong P, de Zeeuw D, Remuzzi G, Kamper AL, Levey AS. Progression risk, urinary protein excretion, and treatment effects of angiotensin-converting enzyme inhibitors in nondiabetic kidney disease. J Am Soc Nephrol 2007; 18: 1959-1965.

43 Sharma P, Blackburn RC, Parke CL, McCullough K, Marks A, Black C. Angiotensinconverting enzyme inhibitors and angiotensin receptor blockers for adults with early (stage 1 to 3) non-diabetic chronic kidney disease. Cochrane Database Syst Rev 2011; 5: CD007751.

44 Mann JF, Schmieder RE, McQueen M, Dyal L, Schumacher H, Pogue J, Wang X, Maggioni A, Budaj A, Chaithiraphan S, Dickstein K, Keltai M, Metsarinne K, Oto A Parkhomenko A, Piegas LS, Svendsen TL, Teo KK, Yusuf S. Renal outcomes with telmisartan, ramipril, or both, in people at high vascular risk (the ONTARGET study): a multicentre, randomised, double-blind, controlled trial. Lancet 2008; 372: 547-553

45 Fried LF, Duckworth W, Zhang JH, O'Connor T, Brophy M, Emanuele N, Huang GD, McCullough PA, Palevsky PM, Seliger S, Warren SR, Peduzzi P. Design of combination angiotensin receptor blocker and angiotensin-converting enzyme inhibitor for treatment of diabetic nephropathy (VA NEPHRON-D). Clin J Am Soc Nephrol 2009; 4: 361-368.

46 O'Hare AM, Kaufman JS, Covinsky KE, Landefeld CS, McFarland LV, Larson EB. Current guidelines for using angiotensin-converting enzyme inhibitors and angiotensin II-receptor antagonists in chronic kidney disease: is the evidence base relevant to older adults? Ann Intern Med 2009; 150: 717-724.

47 Musso CG, Liakopoulos V, loannidis I, Eleftheriadis T, Stefanidis I. Acute renal failure in the elderly: particular characteristics. Int Urol Nephrol 2006; 38: 787-793.

48 Sarafidis PA, Bakris GL. Does evidence support renin-angiotensin system blockade for slowing nephropathy progression in elderly persons? Ann Intern Med 2009; 150 731-733.

49 Hayashi K, Wakino S, Homma K, Sugano N, Saruta T. Pathophysiological significance of T-type $\mathrm{Ca} 2+$ channels: role of T-type $\mathrm{Ca} 2+$ channels in renal microcirculation. J Pharmacol Sci 2005; 99: 221-227.

50 Sasaki H, Saiki A, Endo K, Ban N, Yamaguchi T, Kawana H, Nagayama D, Ohhira M, Oyama T, Miyashita Y, Shirai K. Protective effects of efonidipine, a T- and L-type calcium channel blocker, on renal function and arterial stiffness in type 2 diabetic patients with hypertension and nephropathy. J Atheroscler Thromb 2009; 16: 568-575.

51 Galceran J, Plana J, Felip A, Pou G, Vila J, Sobrino J. Manidipine treatment in patients with albuminuria not sufficiently reduced with renin-angiotensin system blockers. Expert Rev Cardiovasc Ther 2010; 8: 751-757.

52 Martinez-Martin FJ, Saiz-Satjes M. Add-on manidipine versus amlodipine in diabetic patients with hypertension and microalbuminuria: the AMANDHA study. Expert Rev Cardiovasc Ther 2008; 6: 1347-1355
53 Yamamoto E, Kataoka K, Dong YF, Nakamura T, Fukuda M, Nako H, Ogawa H, KimMitsuyama S. Benidipine a dihydropyridine L-type/T-type calcium channel blocker, affords additive benefits for prevention of cardiorenal injury in hypertensive rats. J Hypertens 2010; 28: 1321-1329.

54 Hayashi K, Wakino S, Sugano N, Ozawa Y, Homma K, Saruta T. Ca2 + channe subtypes and pharmacology in the kidney. Circ Res 2007; 100: 342-353.

55 Abe M, Okada K, Maruyama T, Maruyama N, Matsumoto K. Comparison of the antiproteinuric effects of the calcium channel blockers benidipine and amlodipine administered in combination with angiotensin receptor blockers to hypertensive patients with stage 3-5 chronic kidney disease. Hypertens Res 2009; 32: 270-275.

56 Ohta M, Sugawara S, Sato N, Kuriyama C, Hoshino C, Kikuchi A. Effects of benidipine, a long-acting T-type calcium channel blocker, on home blood pressure and renal function in patients with essential hypertension: a retrospective, 'real-world' comparison with amlodipine. Clin Drug Investig 2009; 29: 739-746.

57 Brown MJ, Palmer CR, Castaigne A, de Leeuw PW, Mancia G, Rosenthal T, Ruilope LM. Morbidity and mortality in patients randomised to double-blind treatment with a long-acting calcium-channel blocker or diuretic in the International Nifedipine GITS study: Intervention as a Goal in Hypertension Treatment (INSIGHT). Lancet 2000; 356: 366-372.

58 Voyaki SM, Staessen JA, Thijs L, Wang JG, Efstratopoulos AD, Birkenhager WH, de Leeuw PW, Leonetti G, Nachev C, Rodicio JL, Tuomilehto J, Fagard R. Follow-up of renal function in treated and untreated older patients with isolated systolic hypertension. Systolic Hypertension in Europe (Syst-Eur) Trial Investigators. J Hypertens 2001; 19: 511-519.

59 Rahman M, Pressel S, Davis BR, Nwachuku C, Wright Jr JT, Whelton PK, Barzilay J, Batuman V, Eckfeldt JH, Farber M, Henriquez M, Kopyt N, Louis GT, Saklayen M, Stanford C, Walworth C, Ward H, Wiegmann T. Renal outcomes in high-risk hypertensive patients treated with an angiotensin-converting enzyme inhibitor or a calcium channel blocker vs a diuretic: a report from the Antihypertensive and LipidLowering Treatment to Prevent Heart Attack Trial (ALLHAT). Arch Intern Med 2005; 165: 936-946.

60 Bakris GL, Weir MR, Secic M, Campbell B, Weis-McNulty A. Differential effects of calcium antagonist subclasses on markers of nephropathy progression. Kidney Int 2004; 65: 1991-2002.

61 Remuzzi G, Macia M, Ruggenenti P. Prevention and treatment of diabetic rena disease in type 2 diabetes: the BENEDICT study. J Am Soc Nephrol 2006; 17 S90-S97.

62 Boero R, Rollino C, Massara C, Berto IM, Perosa P, Vagelli G, Lanfranco G, Quarello F. The verapamil versus amlodipine in nondiabetic nephropathies treated with trandolapril (VVANNTT) study. Am J Kidney Dis 2003; 42: 67-75.

63 Eguchi K, Kario K, Shimada K. Effects of long-acting ACE inhibitor (temocapril) and long-acting $\mathrm{Ca}$ channel blocker (amlodipine) on 24-h ambulatory BP in elderly hypertensive patients. J Hum Hypertens 2001; 15: 643-648.

64 Campese VM, Kogosov E. Renal afferent denervation prevents hypertension in rats with chronic renal failure. Hypertension 1995; 25: 878-882.

65 Xu J, Li G, Wang P, Velazquez H, Yao X, Li Y, Wu Y, Peixoto A, Crowley S, Desir GV. Renalase is a novel, soluble monoamine oxidase that regulates cardiac function and blood pressure. J Clin Invest 2005; 115: 1275-1280.

66 Epstein M, Oster JR, Hollenberg NK. Beta-blockers and the kidney: implications for renal function and renin release. Physiologist 1985; 28: 53-63.

67 van Zwieten PA. An overview of the pharmacodynamic properties and therapeutic potential of combined alpha- and beta-adrenoceptor antagonists. Drugs 1993; 45: 509-517.

68 Kalinowski L, Dobrucki LW, Szczepanska-Konkel M, Jankowski M, Martyniec L, Angielski S, Malinski T. Third-generation beta-blockers stimulate nitric oxide release from endothelial cells through ATP efflux: a novel mechanism for antihypertensive action. Circulation 2003; 107: 2747-2752.

69 Gomes A, Costa D, Lima JL, Fernandes E. Antioxidant activity of beta-blockers: an effect mediated by scavenging reactive oxygen and nitrogen species? Bioorg Med Chem 2006; 14: 4568-4577.

70 Mason RP, Kubant R, Jacob RF, Walter MF, Boychuk B, Malinski T. Effect of nebivolo on endothelial nitric oxide and peroxynitrite release in hypertensive animals: Role of antioxidant activity. J Cardiovasc Pharmacol 2006; 48: 862-869.

71 Feuerstein GZ, Ruffolo Jr RR. Carvedilol, a novel vasodilating beta-blocker with the potential for cardiovascular organ protection. Eur Heart J 1996; 17(Suppl B): 24-29.

72 Bakris GL, Fonseca V, Katholi RE, McGill JB, Messerli F, Phillips RA, Raskin P, Wright Jr JT, Waterhouse B, Lukas MA, Anderson KM, Bell DS. Differential effects of betablockers on albuminuria in patients with type 2 diabetes. Hypertension 2005; 46: 1309-1315.

73 Giner V, Tormos C, Chaves FJ, Saez G, Redon J, Microalbuminuria and oxidative stress in essential hypertension. J Intern Med 2004; 255: 588-594.

74 Bakris GL, Fonseca V, Katholi RE, McGill JB, Messerli FH, Phillips RA, Raskin P, Wright Jr JT, Oakes R, Lukas MA, Anderson KM, Bell DS. Metabolic effects of carvedilol vs metoprolol in patients with type 2 diabetes mellitus and hypertension: a randomized controlled trial. JAMA 2004; 292: 2227-2236.

75 Giugliano D, Acampora R, Marfella R, De Rosa N, Ziccardi P, Ragone R, De Angelis L, D'Onofrio F. Metabolic and cardiovascular effects of carvedilol and atenolol in noninsulin-dependent diabetes mellitus and hypertension. A randomized, controlled trial. Ann Intern Med 1997; 126: 955-959.

76 Jacob S, Rett K, WickImayr M, Agrawal B, Augustin HJ, Dietze GJ. Differential effect of chronic treatment with two beta-blocking agents on insulin sensitivity: the carvedilol-metoprolol study. J Hypertens 1996; 14: 489-494. 
77 Bakris GL. Role for beta-blockers in the management of diabetic kidney disease. Am J Hypertens 2003; 16: 7S-12S.

78 Zuanetti G, Maggioni AP, Keane W, Ritz E. Nephrologists neglect administration of betablockers to dialysed diabetic patients. Nephrol Dial Transplant 1997; 12: 2497-2500

79 Epstein M, Oster JR. Beta blockers and renal function: a reappraisal. J Clin Hypertens 1985; 1: 85-99.

80 Abbott KC, Trespalacios FC, Agodoa LY, Taylor AJ, Bakris GL. beta-Blocker use in long-term dialysis patients: association with hospitalized heart failure and mortality. Arch Intern Med 2004; 164: 2465-2471.

81 Wright RS, Reeder GS, Herzog CA, Albright RC, Williams BA, Dvorak DL, Miller WL, Murphy JG, Kopecky SL, Jaffe AS. Acute myocardial infarction and renal dysfunction: a high-risk combination. Ann Intern Med 2002; 137: 563-570.

82 Lindholm LH, Carlberg B, Samuelsson O. Should beta blockers remain first choice in the treatment of primary hypertension? A meta-analysis. Lancet 2005; 366: $1545-1553$.

83 Bradley HA, Wiysonge CS, Volmink JA, Mayosi BM, Opie LH. How strong is the evidence for use of beta-blockers as first-line therapy for hypertension? Systematic review and meta-analysis. J Hypertens 2006; 24: 2131-2141.

84 Hart PD, Bakris GL. Should beta-blockers be used to control hypertension in people with chronic kidney disease? Semin Nephrol 2007; 27: 555-564.

85 Abe M, Okada K, Maruyama T, Matsumoto K. Renoprotect and blood pressure lowering effect of low-dose hydrochlorothiazide added to intensive renin-angiotensin inhibition in hypertensive patients with chronic kidney disease. Int J Clin Pharmacol Ther 2009; 47: 525-532.

86 Segura J, Ruilope LM. Should diuretics always be included as initial antihypertensive management in early-stage CKD? Curr Opin Nephrol Hypertens 2009; 18: 392-396.

87 Brater DC. Use of diuretics in chronic renal insufficiency and nephrotic syndrome. Semin Nephrol 1988; 8: 333-341.

88 De Nicola L, Minutolo R, Gallo C, Zoccali C, Cianciaruso B, Conte M, Lupo A, Fuiano G, Gallucci M, Bonomini M, Chiodini P, Signoriello G, Bellizzi V, Mallamaci F, Nappi F, Conte G. Management of hypertension in chronic kidney disease: the Italian multicentric study. J Nephrol 2005; 18: 397-404.

89 Wright JM, Musini VM. First-line drugs for hypertension. Cochrane Database Syst Rev 2009; 8: CD001841.

90 Messerli FH, Nussberger J, Phung S. Thiazide diuretic monotherapy for hypertension: diuretic's dark side just got darker. Kidney Int 2008; 74: 825 .

91 Elliott WJ. Glucose and cholesterol elevations during thiazide therapy: intention-totreat versus actual on-therapy experience. Am J Med 1995; 99: 261-269.

92 Lithell HO. Effect of antihypertensive drugs on insulin, glucose, and lipid metabolism. Diabetes Care 1991; 14: 203-209.

93 Lindholm LH, Persson M, Alaupovic P, Carlberg B, Svensson A, Samuelsson O. Metabolic outcome during 1 year in newly detected hypertensives: results of the Antihypertensive Treatment and Lipid Profile in a North of Sweden Efficacy Evaluation (ALPINE study). J Hypertens 2003; 21: 1563-1574.

94 Hansson L, Lindholm LH, Niskanen L, Lanke J, Hedner T, Niklason A, Luomanmaki K, Dahlof B, de Faire U, Morlin C, Karlberg BE, Wester PO, Bjorck JE. Effect of angiotensin-converting-enzyme inhibition compared with conventional therapy on cardiovascular morbidity and mortality in hypertension: the Captopril Prevention Project (CAPPP) randomised trial. Lancet 1999; 353: 611-616.

95 Hawkins RG, Houston MC. Is population-wide diuretic use directly associated with the incidence of end-stage renal disease in the United States? A hypothesis. Am J Hypertens 2005; 18: 744-749.

96 Berl T, Katz FH, Henrich WL, de Torrente A, Schrier RW. Role of aldosterone in the control of sodium excretion in patients with advanced chronic renal failure. Kidney Int 1978; 14: 228-235.

97 Hene RJ, Boer P, Koomans HA, Mees EJ. Plasma aldosterone concentrations in chronic renal disease. Kidney Int 1982; 21: 98-101.

98 Brown NJ, Nakamura S, Ma L, Nakamura I, Donnert E, Freeman M, Vaughan DE, Fogo AB. Aldosterone modulates plasminogen activator inhibitor-1 and glomerulosclerosis in vivo. Kidney Int 2000; 58: 1219-1227.

99 Juknevicius I, Segal Y, Kren S, Lee R, Hostetter TH. Effect of aldosterone on renal transforming growth factor-beta. Am J Physiol Renal Physiol 2004; 286: F1059-F1062.

100 Schjoedt KJ, Andersen S, Rossing P, Tarnow L, Parving HH. Aldosterone escape during blockade of the renin-angiotensin-aldosterone system in diabetic nephropathy is associated with enhanced decline in glomerular filtration rate. Diabetologia 2004; 47: 1936-1939.
101 Epstein M. Aldosterone blockade: an emerging strategy for abrogating progressive renal disease. Am J Med 2006; 119: 912-919.

102 Rossing K, Schjoedt KJ, Smidt UM, Boomsma F, Parving $\mathrm{HH}$. Beneficial effects of adding spironolactone to recommended antihypertensive treatment in diabetic nephropathy: a randomized, double-masked, cross-over study. Diabetes Care 2005; 28: 2106-2112.

103 Epstein M, Williams GH, Weinberger M, Lewin A, Krause S, Mukherjee R, Patni R, Beckerman B. Selective aldosterone blockade with eplerenone reduces albuminuria in patients with type 2 diabetes. Clin J Am Soc Nephrol 2006; 1: 940-951.

104 Lindenfeld J, Albert NM, Boehmer JP, Collins SP, Ezekowitz JA, Givertz MM, Katz SD, Klapholz M, Moser DK, Rogers JG, Starling RC, Stevenson WG, Tang WH, Teerlink JR, Walsh MN. HFSA 2010 Comprehensive Heart Failure Practice Guideline. J Card Fail 2010; 16: el-194.

105 Wright Jr JT, Probstfield JL, Cushman WC, Pressel SL, Cutler JA, Davis BR, Einhorn PT, Rahman M, Whelton PK, Ford CE, Haywood LJ, Margolis KL, Oparil S, Black HR, Alderman MH. ALLHAT findings revisited in the context of subsequent analyses, other trials, and meta-analyses. Arch Intern Med 2009; 169: 832-842.

106 Robles NR, Gomez CF, Ocon I, Manjon M, Pastors L, Herrera J, Villatoro J, Calls I, Torrijos I, Rodriguez VI, Rodriguez Martinez MA, Mendez ML, Morey A, Martinez FI, Marco I, Liebana A, Rincon B, Tornero F. Doxazosine associated to renin-angiotensin blockers and calcioantagonists in chronic renal failure patients. Nefrologia 2005; 25: 515-520.

107 van Zwieten PA, Thoolen MJMC, Timmermans PBMWM. The pharmacology of centrally acting antihypertensive drugs. Br J Clin Pharmacol 1983: 15: 455S-462S.

108 van Zwieten PA. Centrally acting antihypertensives: a renaissance of interest. Mechanisms and haemodynamics. J Hypertens Supp/ 1997; 15: S3-S8.

109 van den Meiracker AH, Jan Danser AH. Aliskiren: the first direct renin inhibitor for hypertension. Curr Cardiol Rep 2007; 9: 470-476.

110 Wiggins KJ, Kelly DJ. Aliskiren: a novel renoprotective agent or simply an alternative to ACE inhibitors? Kidney Int 2009; 76: 23-31.

111 Pimenta E, Oparil S. Role of aliskiren in cardio-renal protection and use in hypertensives with multiple risk factors. Vasc Health Risk Manag 2009; 5: 453-463.

112 Parving HH, Persson F, Lewis JB, Lewis EJ, Hollenberg NK. Aliskiren combined with losartan in type 2 diabetes and nephropathy. N Engl J Med 2008; 358: 2433-2446.

113 Parving HH, Brenner BM, McMurray JJ, de ZD, Haffner SM, Solomon SD, Chaturvedi N, Ghadanfar M, Weissbach N, Xiang Z, Armbrecht J, Pfeffer MA. Aliskiren Trial in Type 2 Diabetes Using Cardio-Renal Endpoints (ALTITUDE): rationale and study design. Nephrol Dial Transplant 2009; 24: 1663-1671.

114 Neuhofer W, Pittrow D. Endothelin receptor selectivity in chronic kidney disease: rationale and review of recent evidence. Eur J Clin Invest 2009; 39(Suppl 2): 50-67.

115 Nambi P. Endothelin receptors in normal and diseased kidneys. Clin Exp Pharmacol Physiol 1996; 23: 326-330.

116 de Nucci G, Thomas R, Orleans-Juste P, Antunes E, Walder C, Warner TD, Vane JR. Pressor effects of circulating endothelin are limited by its removal in the pulmonary circulation and by the release of prostacyclin and endothelium-derived relaxing factor. Proc Natl Acad Sci USA 1988; 85: 9797-9800.

117 Jougasaki M, Schirger JA, Simari RD, Burnett Jr JC. Autocrine role for the endothelinB receptor in the secretion of adrenomedullin. Hypertension 1998; 32: 917-922.

118 Plato CF, Pollock DM, Garvin JL. Endothelin inhibits thick ascending limb chloride flux via ET(B) receptor-mediated NO release. Am J Physiol Renal Physiol 2000; 279: F326-F333.

119 Edwards RM, Stack EJ, Pullen M, Nambi P. Endothelin inhibits vasopressin action in rat inner medullary collecting duct via the ETB receptor. J Pharmacol Exp Ther 1993; 267: 1028-1033

120 Ozaki S, Ohwaki K, Ihara M, Fukuroda T, Ishikawa K, Yano M. ETB-mediated regulation of extracellular levels of endothelin-1 in cultured human endothelial cells. Biochem Biophys Res Commun 1995; 209: 483-489.

121 Weber MA, Black H, Bakris G, Krum H, Linas S, Weiss R, Linseman JV, Wiens BL, Warren MS, Lindholm LH. A selective endothelin-receptor antagonist to reduce blood pressure in patients with treatment-resistant hypertension: a randomised, doubleblind, placebo-controlled trial. Lancet 2009; 374: 1423-1431.

122 Wenzel RR, Littke T, Kuranoff S, Jurgens C, Bruck H, Ritz E, Philipp T, Mitchell A. Avosentan reduces albumin excretion in diabetics with macroalbuminuria. J Am Soc Nephrol 2009; 20: 655-664.

123 Liu C, Chen J, Gao Y, Deng B, Liu K. Endothelin receptor antagonists for pulmonary arterial hypertension. Cochrane Database Syst Rev 2009; 8: CD004434.

124 Moore R, Linas S. Endothelin antagonists and resistant hypertension in chronic kidney disease. Curr Opin Nephrol Hypertens 2010; 19: 432-436. 